Vol. 1, No. 2, Jul 2018, hlm. 23 - 32

Available online at http://jurnal.stmikroyal.ac.id/index.php/jurdimas

\title{
PELATIHAN INSTALASI SISTEM OPERASI WINDOWS PADA PERSONAL COMPUTER
}

\author{
Juna Eska ,Afrisawati, M.Ihsan ,M.Pd \\ Program Studi Sistem Informasi, STMIK Royal Kisaran, \\ email: junaeska@ royal.ac.id ,afrisawati@royal.ac.id
}

\begin{abstract}
Abstarct: Increased computer users in high school make increasingly also the desire of students / i equal to know the type of computer components. With the many interests of students to know installation of computers, making their enthusiasm higher in knowing the types of computer applications. Many factors influence for students on computer assembly, such as how component form, type of operating system, and how to install.
\end{abstract}

Keywords: Computer Components, Operating System

\begin{abstract}
Abstak: Peningkatan pengguna komputer di sekolah SMA membuat makin meningkat pula keinginan siswa/i sederajat untuk mengetahui jenis komponen komputer. Dengan banyaknya minat siswa/i untuk mengetahui instalasi komputer, membuat antusias mereka semakin tinggi dalam mengetahui jenis aplikasi komputer. Banyak faktor yang mempengaruhi bagi siswa/i pada instalasi komputer, seperti bagaimana bentuk komponen, jenis sistem operasi, dan bagaimana cara instalasinya.
\end{abstract}

Kata Kunci : Komponen Komputer, Sistem Operasi,

\section{PENDAHULUAN}

Pengabdian kepada masyarakat merupakan pelaksanaan pengalaman ilmu pengetahuan, teknologi dan seni budaya langsung pada masyarakat secara kelembagaan melalui metodologi ilmiah sebagai penyebaran Tri Dharma Perguruan Tinggi serta tanggung jawab yang luhur dalam usaha mengembangkan kemampuan masyarakat, sehingga dapat mempercepat laju pertumbuhan tercapainya tujuan pembanguanan nasional.

Maksud dari kegiatan pengabdian ini adalah melaksanakan Tri Dharma Perguruan Tinggi berupa Pengabdian Kepada Masyarakat sebagai pengamalan ilmu pengetahuan, teknologi khususnya sistem komputer kepada siswa-siswi SMA Swadaya Tinggi Raja oleh dosen STMIK Royal Kisaran

Komputer adalah alat yang dipakai untuk mengolah data menurut prosedur yang telah dirumuskan. Kata computer pada awalnya dipergunakan untuk menggambarkan orang yang perkerjaannya melakukan perhitungan aritmetika, dengan atau tanpa alat bantu, tetapi arti kata ini kemudian dipindahkan kepada mesin itu sendiri. Asal mulanya, pengolahan informasi hampir eksklusif berhubungan dengan masalah aritmetika, tetapi komputer modern dipakai untuk banyak tugas yang tidak berhubungan dengan matematika.

Dalam arti seperti itu terdapat alat seperti slide rule, jenis kalkulator mekanik mulai dari abakus dan seterusnya, sampai semua komputer elektronik yang kontemporer. Istilah lebih baik yang cocok untuk arti luas seperti "komputer" adalah "yang mengolah informasi" atau "sistem pengolah informasi." Selama bertahun-tahun sudah ada beberapa arti yang berbeda dalam kata "komputer", dan beberapa kata yang berbeda tersebut sekarang disebut sebagai 
Vol. 1, No. 2, Jul 2018, hlm. 23 - 32

Available online at http://jurnal.stmikroyal.ac.id/index.php/jurdimas

komputer.

$\begin{array}{llr}\text { Kata } & \begin{array}{l}\text { computer secara } \\ \text { pernah }\end{array} & \text { umum } \\ \text { dipergunakan } & \text { untuk }\end{array}$ mendefiniskan orang yang melakukan perhitungan aritmetika, dengan atau tanpa mesin pembantu. Menurut Barnhart Concise Dictionary of Etymology, kata tersebut digunakan dalam bahasa Inggris pada tahun 1646 sebagai kata untuk "orang yang menghitung" kemudian menjelang 1897 juga digunakan sebagai "alat hitung mekanis". Selama Perang Dunia II kata tersebut menunjuk kepada para pekerja wanita Amerika Serikat dan Inggris yang pekerjaannya menghitung jalan artileri perang dengan mesin hitung.

Charles Babbage mendesain salah satu mesin hitung pertama yang disebut mesin analitikal.Selain itu, berbagai alat mesin sederhana seperti slide rule juga sudah dapat dikatakan sebagai komputer.

Sekalipun demikian, definisi di atas mencakup banyak alat khusus yang hanya bisa memperhitungkan satu atau beberapa fungsi. Ketika mempertimbangkan komputer modern, sifat yang paling membedakan mereka dari alat penghitung yang terdahulu ialah dengan pemrograman yang benar, semua komputer dapat mengemulasi sifat apa pun (meskipun barangkali dibatasi oleh kapasitas penyimpanan dan kecepatan yang berbeda), dan, memang dipercaya bahwa mesin sekarang bisa meniru alat perkomputeran yang akan diciptakan manusia pada masa depan (meskipun niscaya lebih lambat). Dalam suatu pengertian, batas kemampuan ini adalah tes yang berguna karena mengenali komputer "maksud umum" dari alat maksud istimewa yang lebih awal. Definisi dari "maksud umum" bisa diformulasikan ke dalam syarat bahwa suatu mesin harus dapat meniru Mesin Turing universal. Mesin yang mendapat definisi ini dikenal sebagai Turinglengkap, dan yang pertama kali muncul pada tahun 1940 di tengah kesibukan perkembangan di seluruh dunia. Lihat artikel sejarah perkomputeran untuk lebih banyak detail periode ini.

\section{METODE}

Materi pengabdian kepada masyarakat disusun sesuai dengan tujuan yang ingin dicapai diantaranya mengenai : mengenal jenis dan hardware-hardware komputer,instalasi system operasi baik windows maupun ubuntu dan workstation (XP dan Windows 7), mengenal sistem operasi, konfigurasi 2 windows, dan lainnya.

Metode pelaksaan dalam pengabdian masyarakat ini adalah dengan cara melaksanakan kegiatan pelatihan dalam bentuk workshop, dengan menjelaskan dasar teori dan praktek langsung.
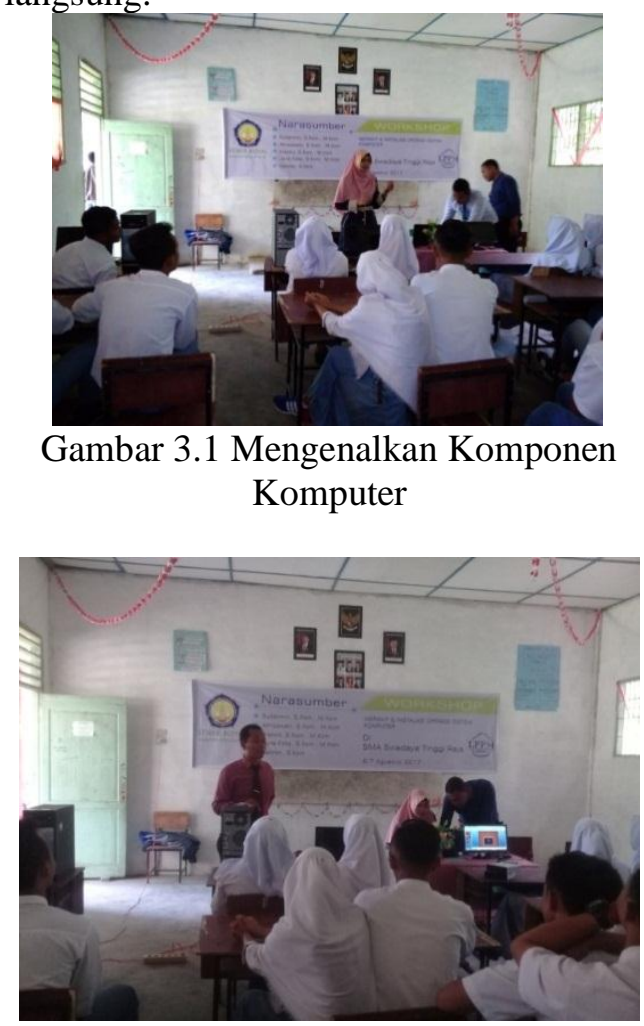

Gambar 3.2 Memulai Instalasi Komputer

\section{PEMBAHASAN}

Operating System Windows 7 merupakan salah satu dari beberapa 
Vol. 1, No. 2, Jul 2018, hlm. 23 - 32

Available online at http://jurnal.stmikroyal.ac.id/index.php/jurdimas

produk Microsoft yang pada saat ini lagi booming, paling banyak penggunanya.

Berikut adalah beberapa tahap

Cara Install Windows 7

1. Pastikan dari BIOS booting komputer Anda di setting untuk DVD

2. Masukkan DVD windows 7

3. Tekan sembarang tombol saat muncul boot from cd or dvd

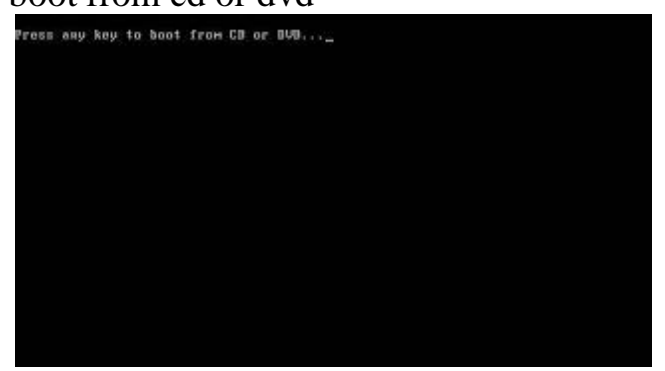

Gambar 4.15 Bootng CD

4. Akan terlihat gambar seperti dibawah ini

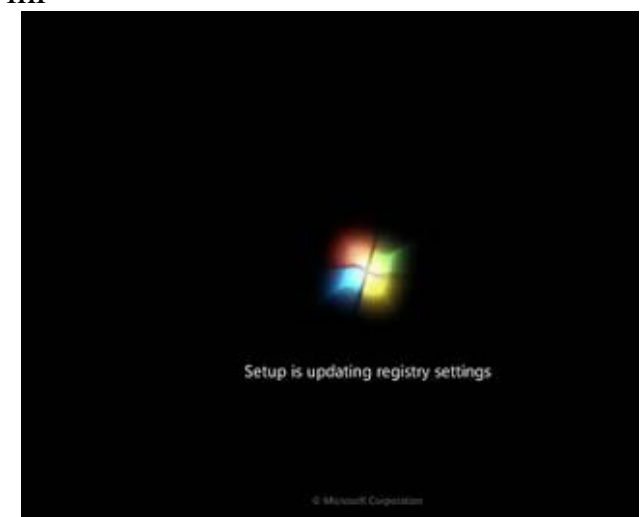

Gambar 4.16 Loading Windows 7

5. Pilih Indonesian pada Language, time, currency, and location

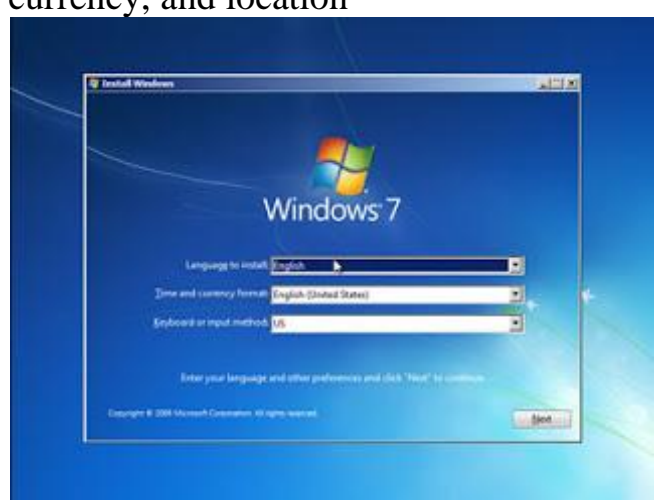

Gambar 4.17 Memilih Nama Negara

6. Tekan tombol install now

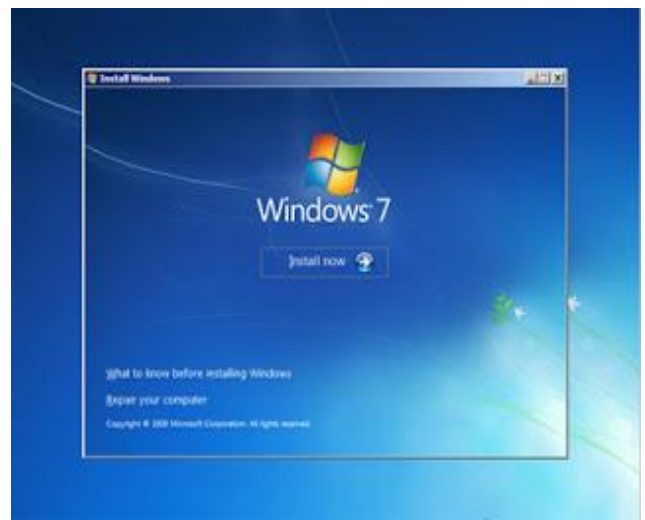

Gambar 4.18 Tampilan Menu Instal 7. Tunggulah beberapa saat proses ini

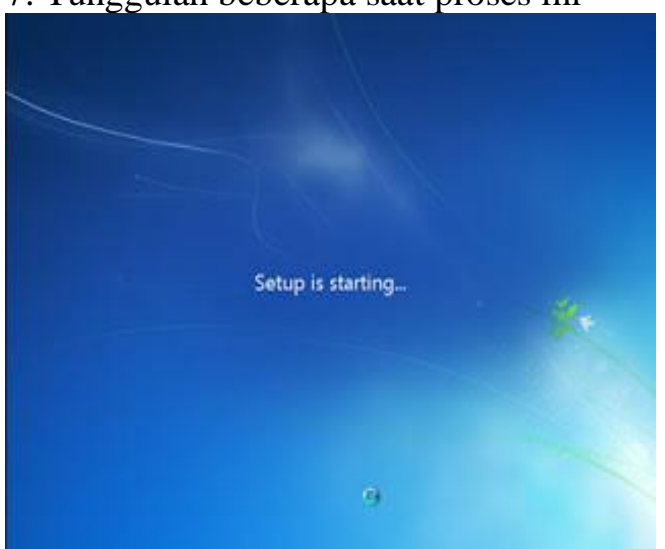

Gambar 4.19 Proses

8. Centang pada I accept the license terms sebagai persetujuan penggunaan windows 7 kemudian klik next

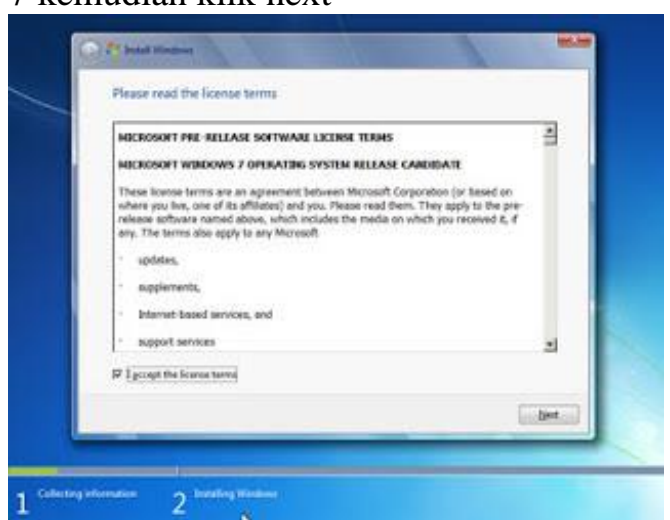

Gambar 4.20 Menyetujui Ketentuan dari Microsoft

9. Karena sedang melakukan clean install maka pilih saja custom (advanced) untuk memilih di drive mana windows 7 akan di install. 
Vol. 1, No. 2, Jul 2018, hlm. 23 - 32

Available online at http://jurnal.stmikroyal.ac.id/index.php/jurdimas

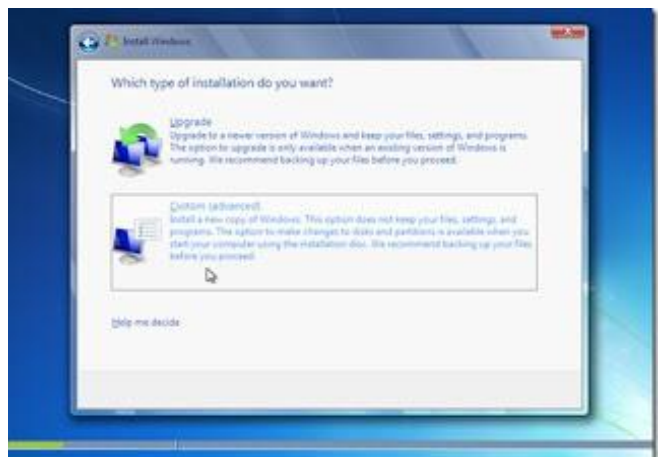

Gambar 4.21 Pilihan Custom

10. Di tahap ini kamu bisa melakukan partisi atau membagi Hardisk kedalam beberapa drive, dimana nanti untuk windows 7 berada pada drive (C) dan sisanya drive (D) untuk penyimpanan data kamu nantinya. Atau jika kamu mau partisi setelah instalasi windows 7 langsung saja klik "Next".Biasanya saya langsung klik next, untuk partisinya belakangan.

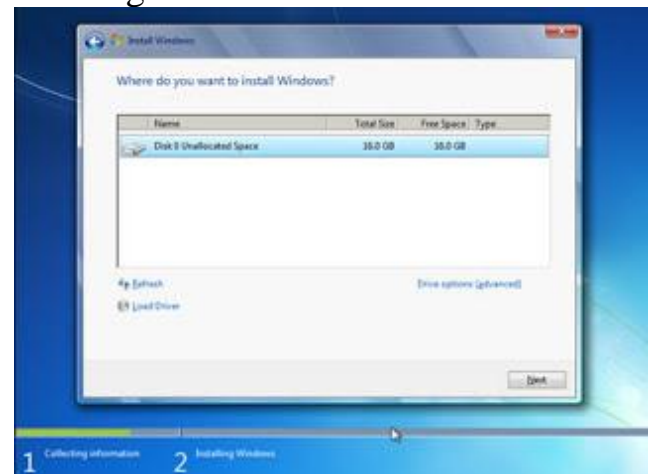

Gambar 4.22 Memilih Drive yang Akan di gunakan

11. Tunggulah proses ini beberapa saat

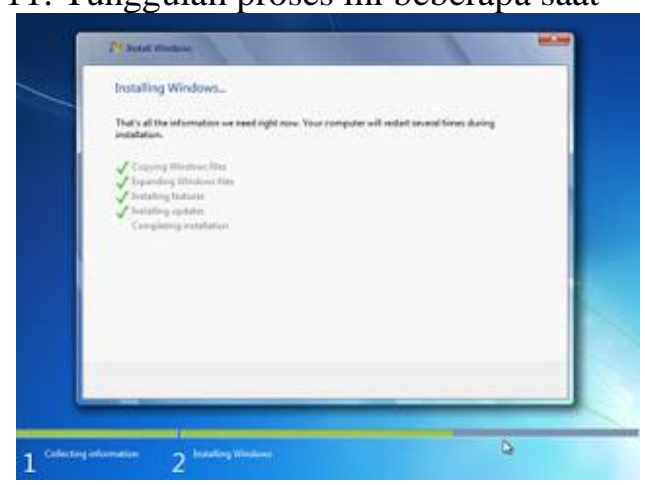

Gambar 4.23 Proses Penyelesaian 12. Secara otomatis windows akan restart

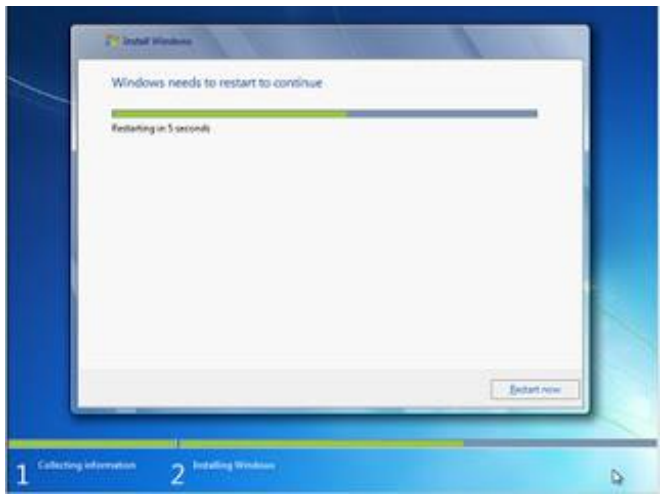

Gambar 4.24 Proses Restart

13. Setelah restart akan muncul gambar berikut ini

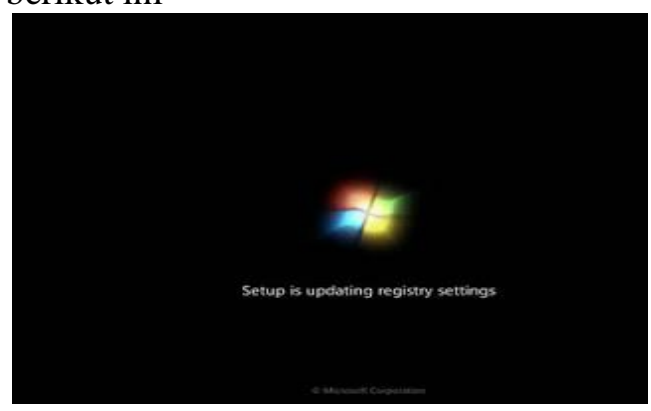

Gambar 4.25 Setekah Restart

14. Tunggulah proses Setting up the services hanya beberapa saat saja

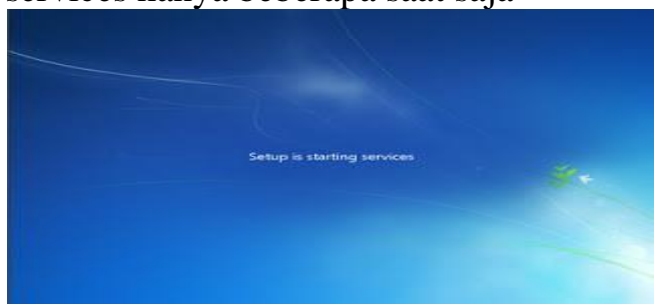

Gambar 4.26 Setting Up

15. Instalasi akan dilanjutkan secara otomatis

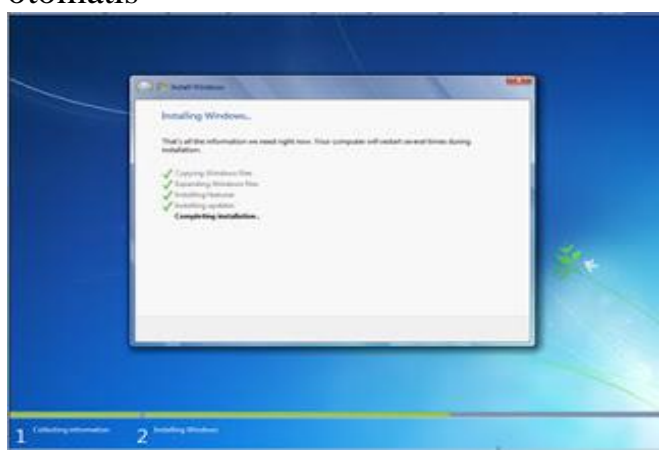

Gambar 4.27 Lanjutan Istalasi

16. Masukkan Nama User dan Nama Komputer sesuka Anda 
Vol. 1, No. 2, Jul 2018, hlm. 23 - 32

Available online at http://jurnal.stmikroyal.ac.id/index.php/jurdimas

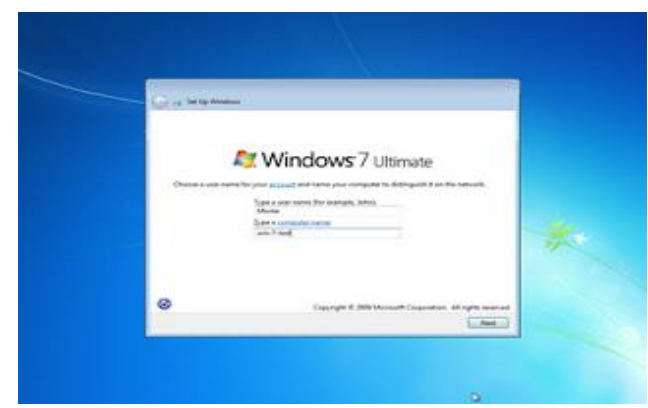

Gambar 4.28 Masukkan Nama User

17. Jika perlu password ketikkan passtwordnya 2 kali atau kosongkan saja jika Anda tidak ingin mempassword user Anda

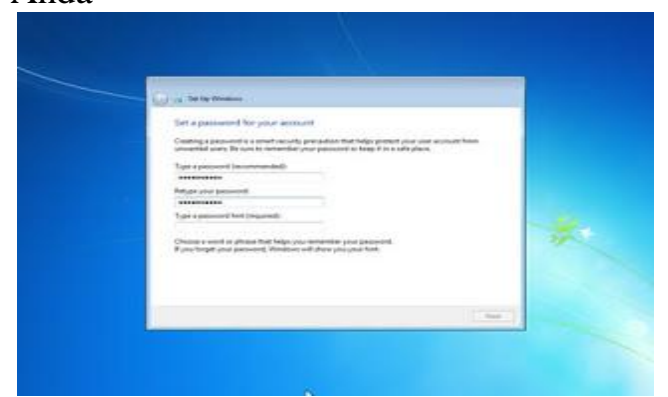

Gambar 4.29 Masukkan Password (Jika di Perlukan)

18. Masukkan product key serial number windows 7 Anda

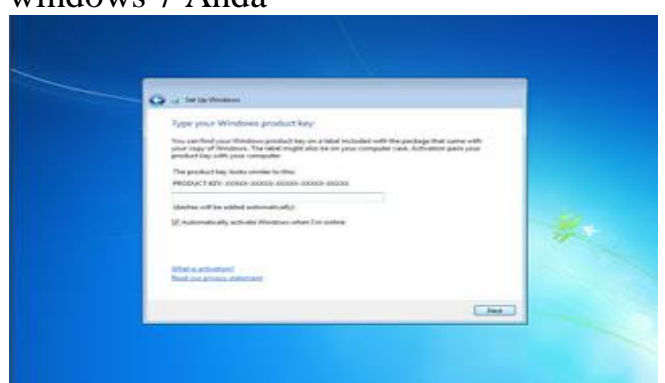

Gambar 4.30 Masukkan Serial Number 19. Pilihlah level proteksi keamanan dari Microsoft

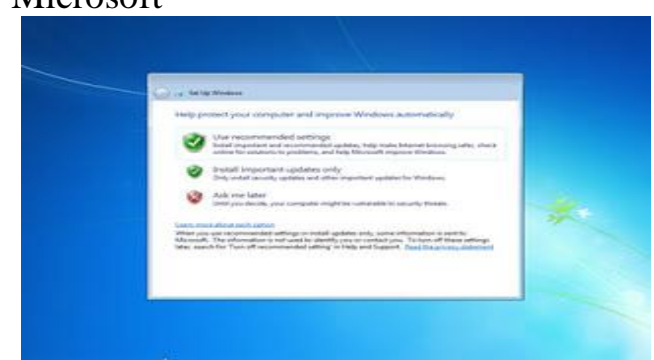

Gambar 4.31 Pilihan level

20. Atur Zona waktu Anda (untuk Indonesia +7 dari GMT)

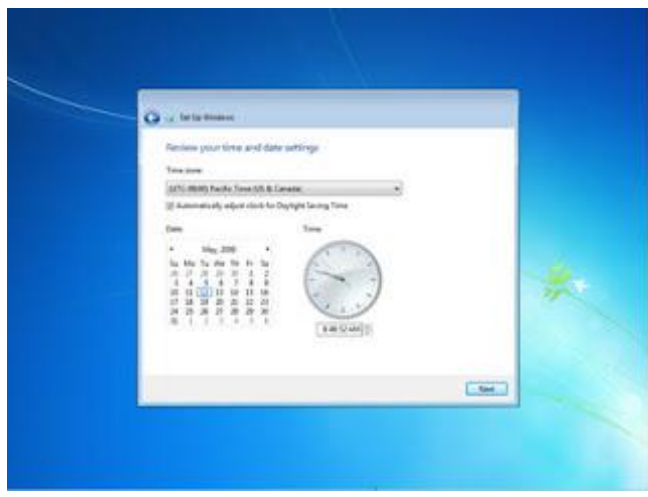

Gambar 4.32 Atur Zona Waktu 21. Selamat, windows 7 Anda siap digunakan

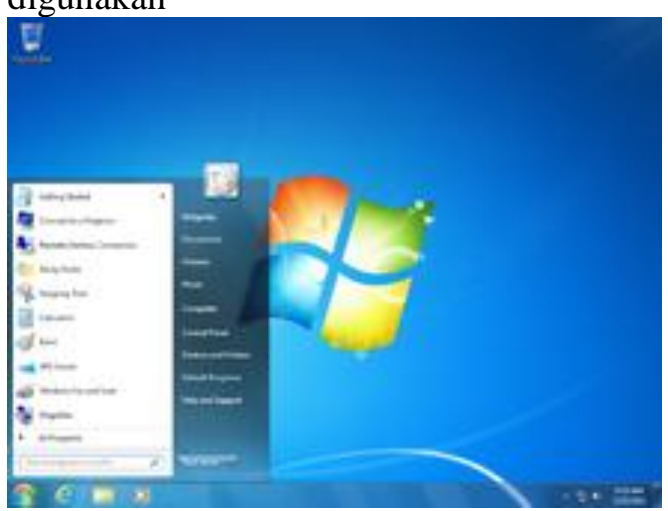

Gambar 4.33 Tampilan Utama Windows 6. Instalasi Sistem Operasi Linux (Ubuntu)

Ubuntu merupakan salah satu distro yang ada pada sistem operasi Linux.Ubuntu merupakan turunan dari distro linux lainnya yaitu debian. Ubuntu saat ini telah mencapai versi 17.04 , maksudnya adalah ubuntu versi ini diluncurkan pada tahun 2017 pada bulan 04 (April) dan akan terus muncul versi terbaru berikutnya. Jika ingin membuat Dual OS antara Windows dan Ubuntu, maka sebaiknya buat terlebih dahulu partisi baru untuk menyimpan file sistem Ubuntu.

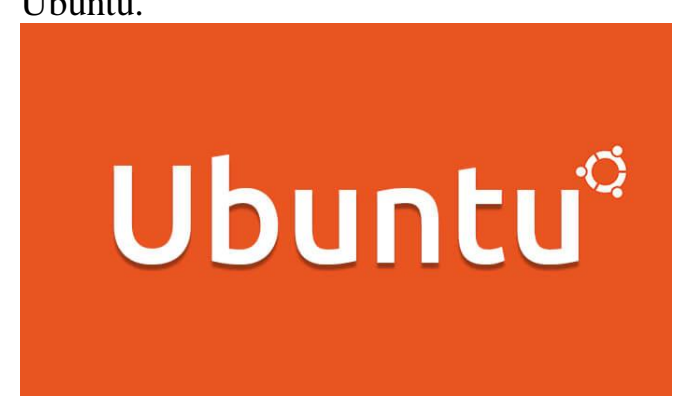

Gambar 4.34 Tampilan Logo Ubuntu 


\section{Jurdimas (Jurnal Pengabdian Kepada Masyarakat) Royal}

Vol. 1, No. 2, Jul 2018, hlm. 23 - 32

ISSN 2614-7912 (cetak)

ISSN 2622-3813 (online)

Available online at http://jurnal.stmikroyal.ac.id/index.php/jurdimas

1. Masukkan CD/DVD master ubuntu 15.04

2. Pastikan CD/DVD dapat dibaca oleh komputer dengan baik.

3. Restart Komputer.

4. Masuk ke pengaturan BIOS terlebih dahulu. Pilih bada bagian menu BOOT, lalu tempatkan CD/DVD pada posisi booting pertama (paling atas).Kemudian simpan.

5. Biarkan komputer restart otomatis dan tunggu proses selanjutnya.

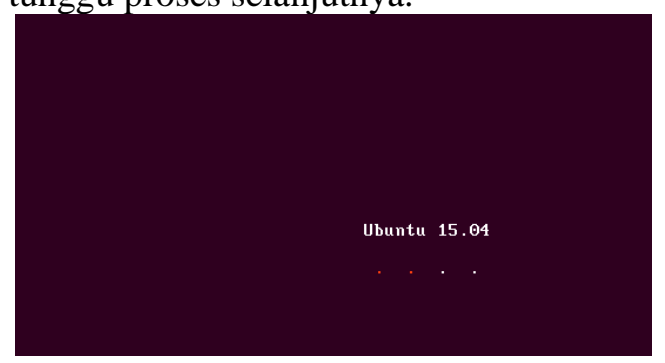

Gambar 4.35 Tampilan Load Ubuntu

Selanjutnya pilih bahasa yang akan digunakan selama penginstalan nantinya. Disini kami menggunakan bahasa English.Selanjutnya klik Install Ubuntu.

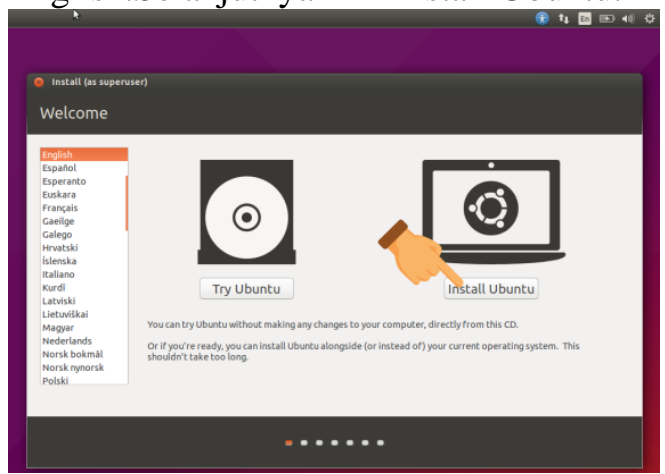

Gambar 4.36 Tampilan Pemilihan Bahasa Pada tahap ini tidak perlu ada yang dirubah atau dicentang, klik Continue saja untuk melanjutkan.

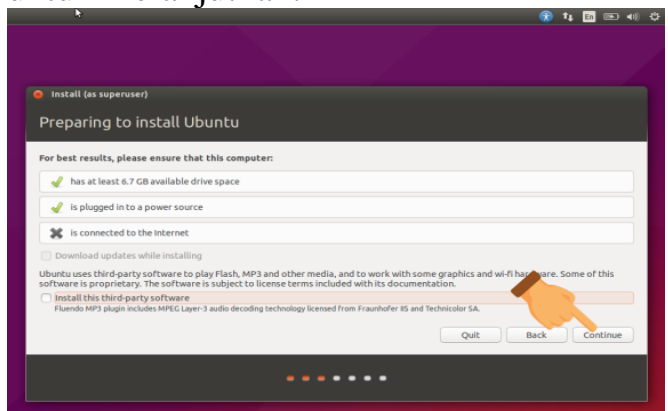

Gambar 4.37 Proses Instalasi
Pada tahap ini akan ada 2 pilihan opsi. Pilih opsi kedua (Something Else) >> Klik Continue.

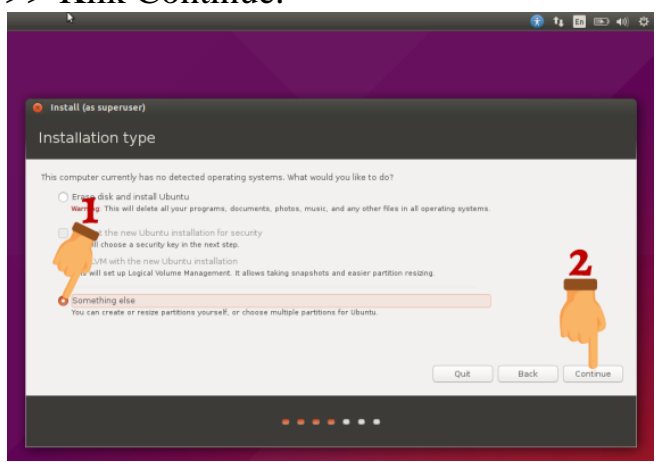

Gambar 4.38 Memilih Type Instalasi

Selanjutnya kita akan membuat sebuah partisi baru dan mengatur partisi pada hard disk. Klik New Partition Table.

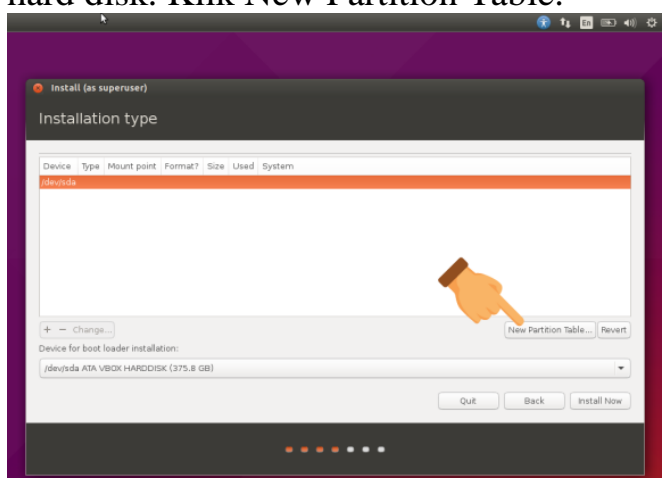

Gambar 4.39 Memilih Partisi

Klik Continue.

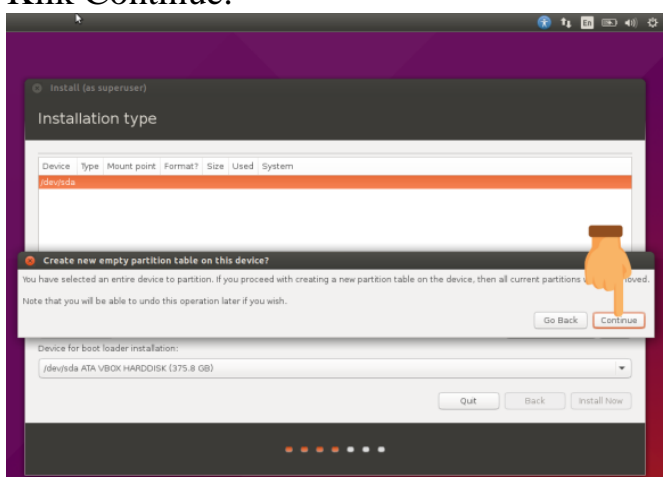

Gambar 4.40 Memilih Partisi

Kita mempunyai hard disk dengan kapasitas 350GB yang nantinya akan dibagi menjadi 2 partisi. Untuk membuat sebuah partisi klik tanda plus (tambah). 
Vol. 1, No. 2, Jul 2018, hlm. 23 - 32

Available online at http://jurnal.stmikroyal.ac.id/index.php/jurdimas

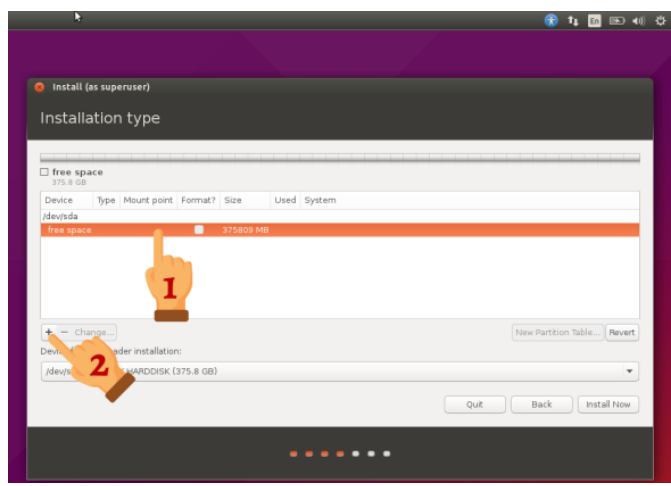

Gambar 4.41 Memilih Ruang Kapasitas

Harddisk

Partisi pertama yaitu kita membuat sebuah partisi dimana data-data akan disimpan, baik data penginstalannya maupun data yang lainnya.

Pertama tentukan ukuran yang akan dibuat pada partisi ini. Selanjutnya pilih Primary >> Beginning of this space.

Pada kotak Use as pilih Ext4 journaling file system >> Pilih / >> Kemudian klik OK.

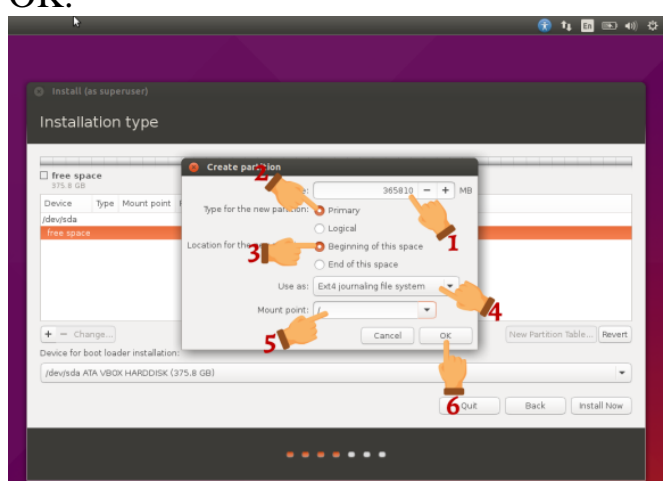

Gambar 4.42 Memilih Primary

Selanjutnya kita akan membuat partisi kedua. Klik tanda plus (tambah) terlebih dahulu, lalu akan muncul tampilan seperti gambar di bawah ini.

Tentukan kapasitas pada partisi ini. Lalu pilih Logical >> Beginning of this space. Pada kotak Use as pilih Swap area. Bagi saya partisi swap area ini merupakan partisi yang penting (wajib). Swap area merupakan sebuah partisi yang nantinya akan menjadi Memory Virtual dengan menggunakan hard disk sebagai medianya. Lalu klik OK.

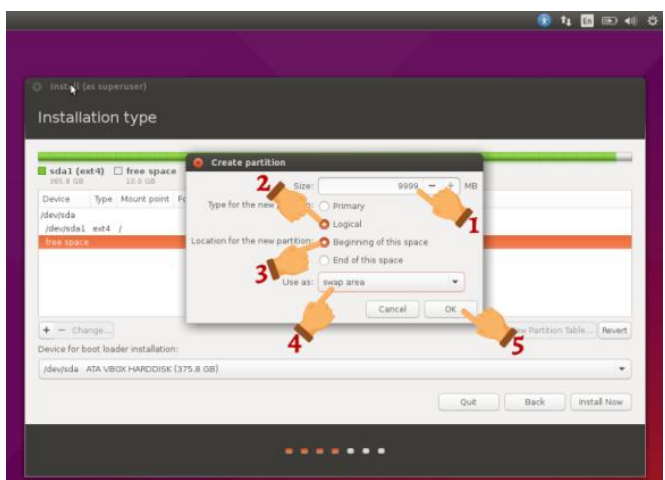

Gambar 4.43 Memilih Area

Maka hasilnya akan terlihat seperti pada gambar di bawah. Kita telah selesai membuat 2 buah partisi, yaitu / dan swap area.

Selanjutnya klik Install Now.

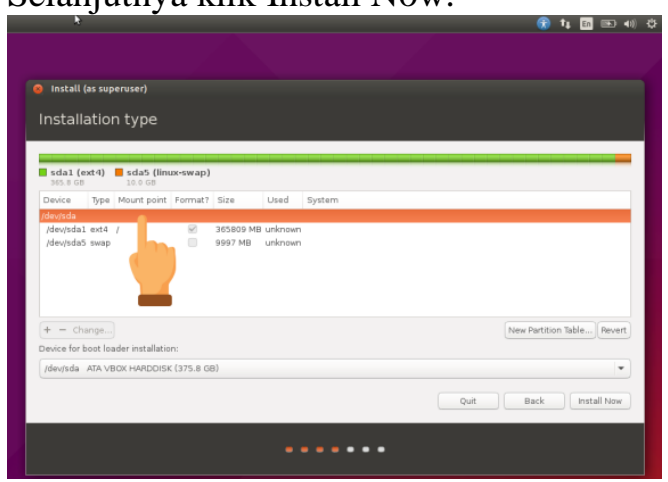

Gambar 4.44 Membuat 2 Buah Partisi Klik Continue.

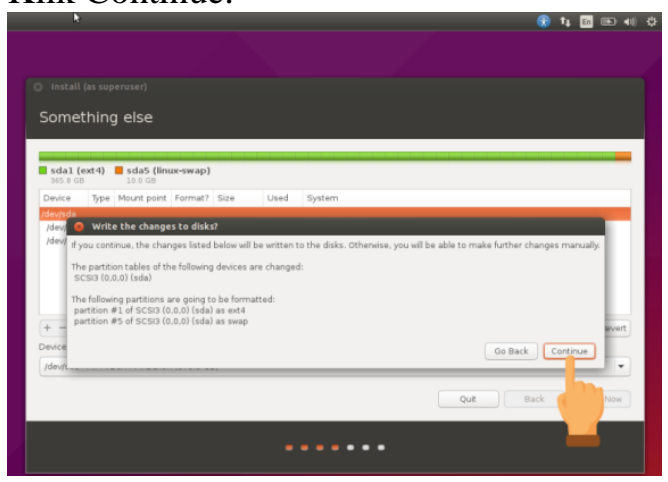

Gambar 4.45 Clik Continue

Pilih zona waktu negara anda (Jakarta, Indonesia) > Klik Continue. 
Vol. 1, No. 2, Jul 2018, hlm. 23 - 32

Available online at http://jurnal.stmikroyal.ac.id/index.php/jurdimas

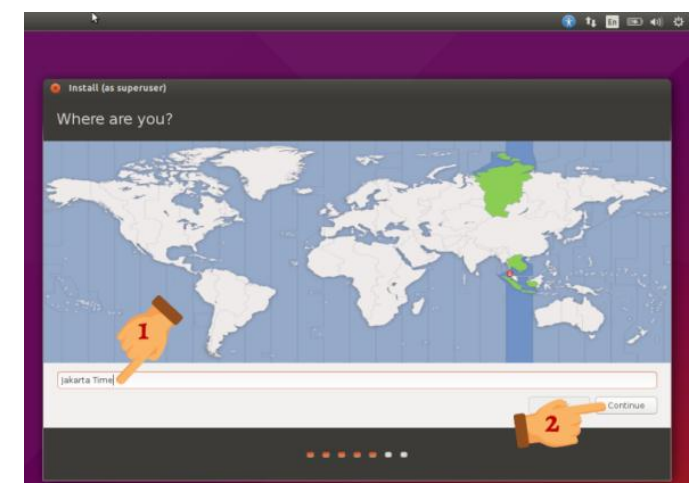

Gambar 4.46 Memilih Lokasi Negara

Selanjutnya pilih bahasa inputan keyboard atau biarkan mengikuti default saja.Kami menggunakan English (US).

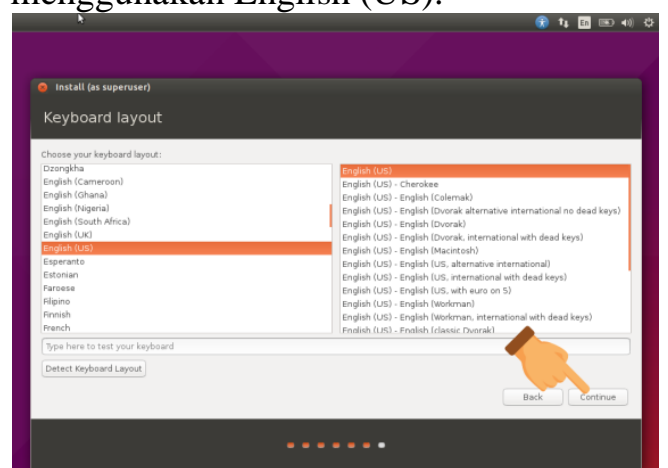

Gambar 4.47 Memilih Inputan Keyboard Selanjutnya yaitu Anda disuruh untuk mengisikan data untuk user secara lengkap.Isikan dengan data yang benar dan gampang di ingat passwordnya.Setelah selesai klik Continue.

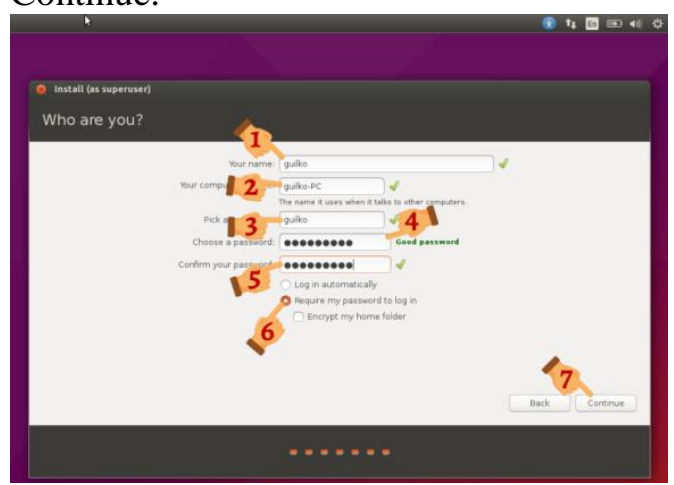

Gambar 4.48 Memasukkan User dan Password

Proses penginstalan dan penyalinan data sistem operasi dimulai. Tunggu proses ini sampai selesai. Biasanya waktu yang dibutuhkan pada tahap ini sekitar 10-20 menit.

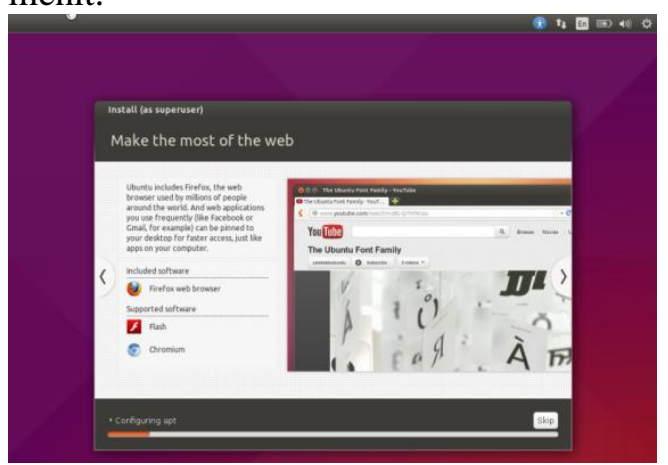

Gambar 4.49 Copy File

Setelah proses penginstalan selesai, maka akan ada perintah seperti pada tampilan di bawah. Klik Restart Now.

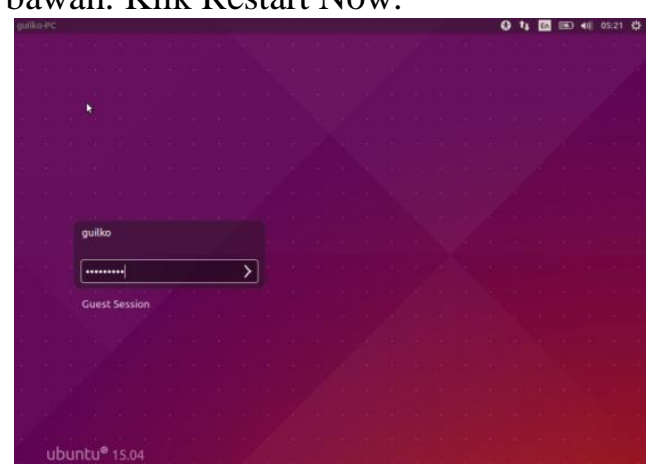

Gambar 4.50 Masukkan Password

Proses penginstalan telah selesai.

Instalasi Aplikasi

VLC Merupakan program aplikasi multimedia, double klik setup.exe

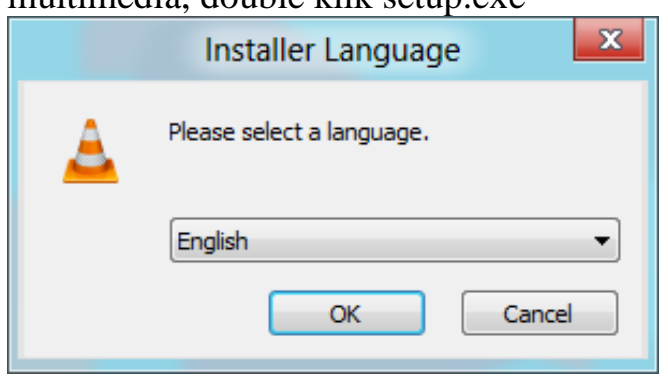

Gambar 4.76 Memilih Bahasa

2. layar Selamat Datang

VLC dimulai dengan selamat datang.lalu klikNEXT. 
Vol. 1, No. 2, Jul 2018, hlm. 23 - 32

Available online at http://jurnal.stmikroyal.ac.id/index.php/jurdimas

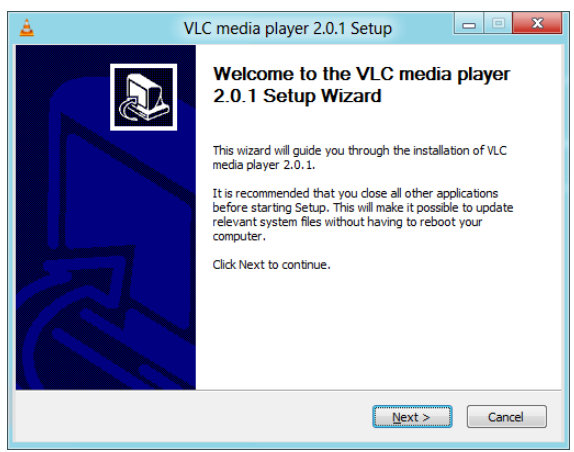

Gambar 4.77 Klik Next

3. Perjanjian Lisensi

Perjanjian lisensi klik sajaNEXT.

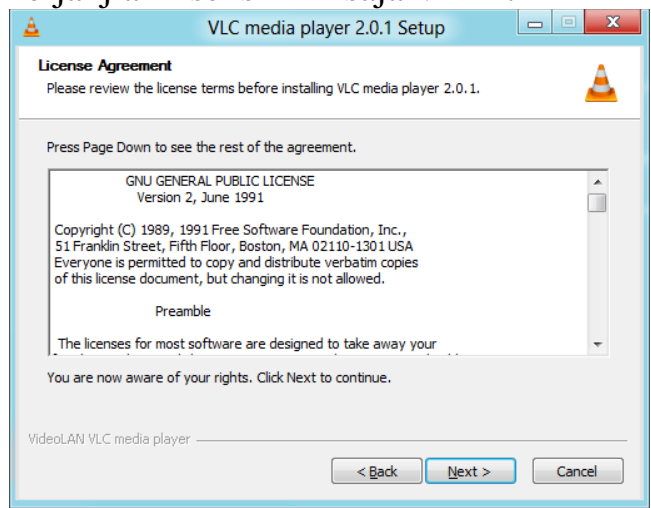

Gambar 4.78 Perjanjian Lisensi

4. Pilih Komponen

Menu ini menyediakan Anda dengan kemampuan untuk menyesuaikan instalasi Anda.

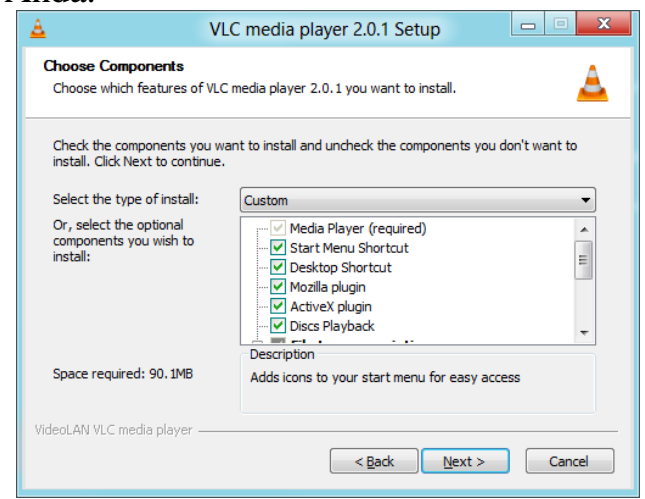

Gambar 4.79 Memilih Komponen

5. Pilih lokasi

Anda memilih folder instalasi dengan Browse ..., lalu klik INSTALL..

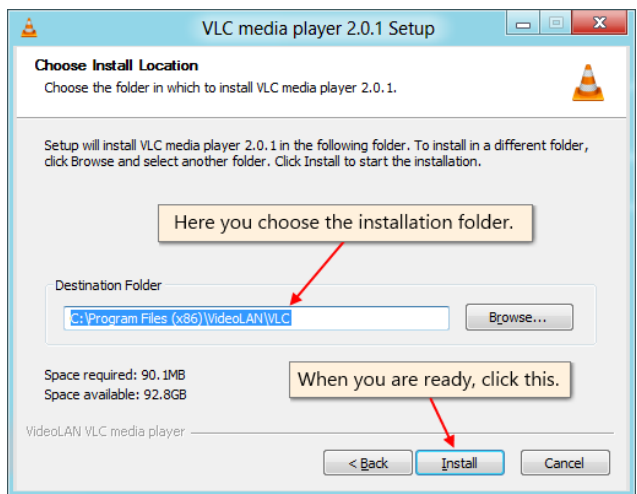

Gambar 4.80 Memilih Lokasi

5. Sekarang menginstal

Tunggu sampai proses menginstal.

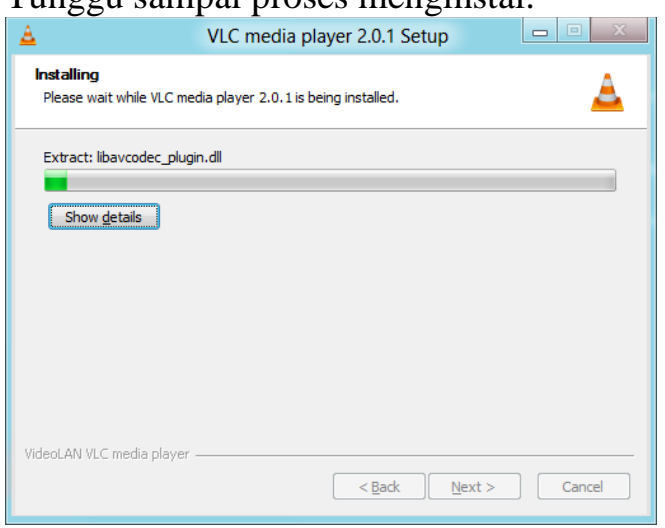

Gambar 4.81 Proses

7. Instalasi lengkap

Setelah instalasi selesai, Anda dapat Menjalankan VLC.FINISH

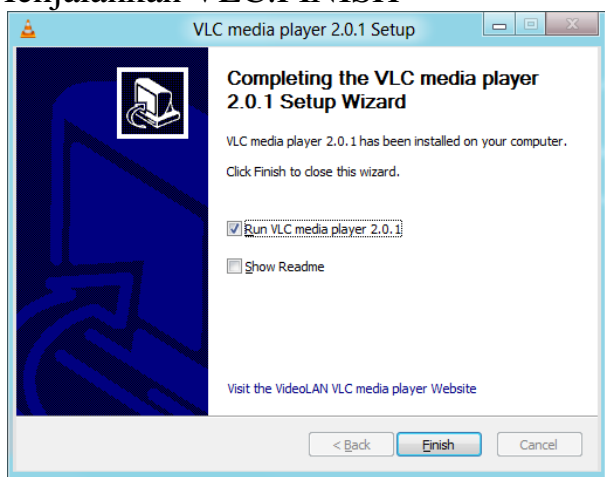

Gambar 4.82 Selesai

7.2 Instalasi Winrar

1. WinRAR.exe Klik 2x.Kemudian Klik Install tombol di bagian bawah. 
Vol. 1, No. 2, Jul 2018, hlm. 23 - 32

Available online at http://jurnal.stmikroyal.ac.id/index.php/jurdimas

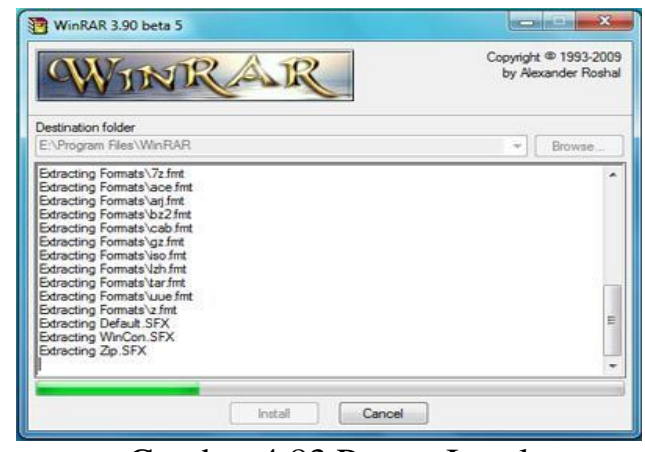

Gambar 4.83 Proses Instal

2. Pilih format yang Anda ingin. Centang semua Kemudian Klik "OK"

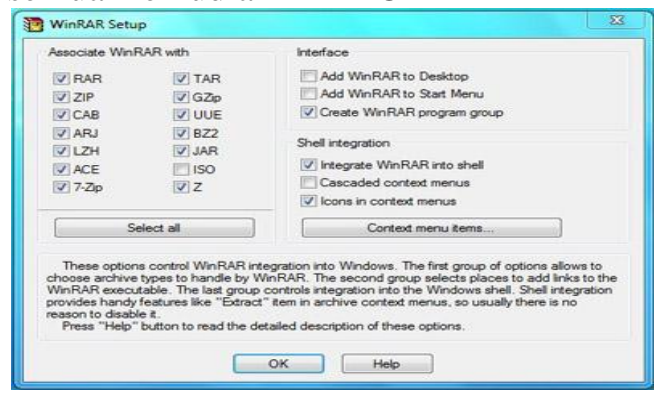

Gambar 4.84 Memilih Jenis File

3. Dalam dialog ini Anda memiliki lima pilihan, jika Anda ingin menjalankan winrar, klik Jalankan WinRAR tombol. Lalu klik "Done"

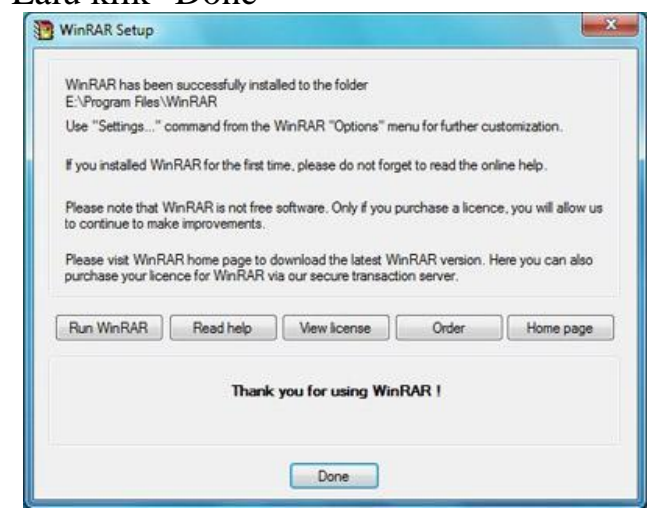

Gambar 4.85 Selesai

\section{SIMPULAN}

Kesimpulan dari kegiatan pengabdian kepada masyarakat di SMA Swadaya Tinggi Raja ini adalah :

1. Mengenal komponen komputer merupakan suatu kebutuhan untuk mengenal personal computer.

2. Dengan adanya tutorial mengintstall computer lebih mudah kita untuk pelaksanaan pengintstalan computer.

\section{DAFTAR PUSTAKA}

MediaCom. "Belajar Mudah Merakit Komputer", Yogyakarta, Raya Fahreza,

Kunci Aksara. "Merakit Komputer Semudah Membalikan Telapak Tangan (2014)", Yogyakarta, Allawi Duratun Fatwa 